\title{
Parafunctional habits and its association with the level of physical activity in adolescents
}

\author{
Hábitos parafuncionais e sua associação com o nível de atividade física em adolescentes
}

Gabriela Navarro¹, Aline Fernanda Baradel ${ }^{1}$, Larissa Canzanese Baldini ${ }^{1}$, Natália Navarro², Ana Lúcia Franco-Micheloni³ ${ }^{2}$ Karina Eiras Dela Coleta Pizzol ${ }^{4}$

DOI 10.5935/2595-0118.20180010

\section{ABSTRACT}

BACKGROUND AND OBJECTIVES: Physical activities are considered beneficial to reduce daily stress. If not eliminated, stress is able to promote large increases in muscle tension, hypertension, asthma, heart arrhythmia and the development of parafunctions. Then, the aim of this study is to evaluate the association between the presence of parafunctional habits and the practice of physical activity in adolescence.

METHODS: The sample comprised of 200 adolescents, boys and girls, from 10 to 19 years old, recruited from the clinics of the Dentistry Course of the University of Araraquara or from public and private schools from the city. The presence of parafunctional oral habits, daytime teeth clenching, and sleep bruxism was obtained through a self-report questionnaire (yes/no). The individuals answered a questionnaire to identify the practice of physical activity according to the instrument adopted in the National School Health Survey (PeNSE - 2012). For the associations, subjects were divided according to the practice of physical activity into active ( $>300$ minutes of activity in the week) or inactive ( $\leq 300$ minutes of activity in the week).

RESULTS: It was observed that boys practiced more physical activity and for a longer period when compared to girls. However, the practice of exercises did not present a significant association with the presence, quantity or type of the oral parafunction $(p>0.05)$.

CONCLUSION: The level of physical activity is not associated with oral parafunction nor with extrafacial pain areas.

Keywords: Adolescent, Exercise, Habits.

1. Universidade de Araraquara, Faculdade de Odontologia, Araraquara, SP, Brasil.

2. Universidade de Araraquara, Faculdade de Odontologia, Programa de Pós-graduaçáo em Ciências Odontológicas, Área de Concentraçăo em Ortodontia, Araraquara, SP, Brasil.

3. Universidade de Araraquara, Disciplinas de Oclusão, Terapêutica, Prótese Total e Removível, Araraquara, SP, Brasil.

4. Universidade de Araraquara, Disciplinas de Ortodontia e Oclusăo, Araraquara, SP, Brasil.

Submitted in June 23, 2017.

Accepted for publication in January 23, 2018

Conflict of interests: none - Sponsoring sources: none

Correspondence to:

Av. Maria Antônia Camargo de Oliveira, 170 - V. Suconasa

14807-120 Araraquara, SP, Brasil.

E-mail: analu.franco@hotmail.com

(c) Sociedade Brasileira para o Estudo da Dor
RESUMO

JUSTIFICATIVA E OBJETIVOS: A prática de atividades físicas é considerada uma forma benéfica de redução de estresse diário. Quando não eliminado, o estresse é capaz de promover grande aumento de tensão muscular, hipertensão, asma, arritmias cardíacas e desenvolvimento de parafunçóes. Assim, o objetivo deste estudo foi avaliar a associação entre a presença de hábitos parafuncionais e a prática de atividade física na adolescência. MÉTODOS: A amostra foi composta por 200 adolescentes, de ambos os sexos, com idade entre 10 e 19 anos, recrutados das clínicas do Curso de Odontologia da Universidade de Araraquara ou de escolas públicas e particulares do município. A presença de hábitos parafuncionais orais, apertamento diurno e de bruxismo do sono foram rastreados por meio de um questionário de autorrelato ( $\mathrm{sim} / \mathrm{não}$ ). Os indivíduos responderam a um questionário para a identificação da prática de atividade física de acordo com o instrumento adotado na Pesquisa Nacional de Saúde do Escolar (PeNSE - 2012). Para o estudo de associação, os indivíduos foram divididos em relação à prática de atividade física em ativos (>300 minutos de atividade na semana) e inati$\operatorname{vos}(\leq 300$ minutos de atividade na semana).

RESULTADOS: Observou-se que os meninos praticam mais atividade física e por mais tempo quando comparado às meninas, entretanto, a prática de exercícios não apresentou associação significativa com a presença, quantidade ou o tipo de hábito parafuncional, e nem com a presença de dor extrafacial ( $p>0,05)$. CONCLUSÁO: $O$ nível de atividade física não se associou à parafunção oral nem com pontos de dor extrafacial.

Descritores: Adolescente, Exercício, Hábitos.

\section{INTRODUCTION}

The World Health Organization (WHO) defines adolescence as the period of life that starts at the age of 10 and finishes at complete 19 years. It is a period characterized by great physical, psychological, and social transformations ${ }^{1}$ that can lead to parafunctional habits ${ }^{2,3}$. When such habits exceed the limit of physiological tolerance of the individual, it can result in aggression to the stomatognathic system ${ }^{4,5}$.

According to the American Academy of Orofacial Pain (AAOP) and the American Association of Sleep Disorders, bruxism is characterized by an involuntary sleep/awake parafunctional activity of the masticatory muscles, rhythmic or in spasm, and may present teeth clenching and/or grinding ${ }^{6}$. Currently, publications 
suggest that bruxism should be considered separately from parafunctions, as well as daytime clenching, due to their different pathophisiology ${ }^{7}$. Both conditions generate peripheral sensitization leading to acute local pain due to the release of inflammatory substances in muscle and joint tissue. Peripheral sensitization, when not resolved (by the absence of effective treatment), becomes a source of continuous pain in the tissue that leads to central sensitization ${ }^{4,8-12}$.

Although daytime bruxism and clenching have a multifactorial origin, psychoemotional aspects, such as stress, anxiety, and depression are directly linked to their onset and maintenance ${ }^{4}$. There is no doubt that the practice of physical exercises is an excellent method to vent daily stress. When not released, the state of tension and stress can increase muscle tone/craniocervical tension, hypertension, asthma, cardiac arrhythmias and the development of parafunctions ${ }^{4}$. Sedentariness is currently one of the major problems of modernity, and it also reaches the teenager directly. Unfortunately, the compliance with exercise programs is still a fundamental problem. The lack of time, lack of interest and lack of social support are the most common indicators of this problem ${ }^{13}$. Physically active adolescents may have reduced risk of chronic diseases (diabetes, hypertension, obesity) in adulthood since the practice of regular physical activity helps to control the body mass, to lower blood pressure, improve psychological well-being, and bring social benefits in all life stages ${ }^{14}$. Studies involving the practice of physical activity in childhood and adolescence, and its relationship with the onset of parafunctional habits, bruxism or even temporomandibular disorders (TMD) are still very scarce and show the importance to detect and intervene early to minimize possible losses ${ }^{15}$.

Given the scarcity of information and scientific evidence about this theme, the present study aimed at identifying the presence of parafunctional habits in teenagers and confirm its possible association with the practice of physical activity.

\section{METHODS}

The sample was composed of 200 teenagers, aged between 10 and 19 years, of both genders, registered for dental care at the University of Araraquara (UNIARA), or recruited in public and private schools of the municipality.

For the sample calculation, it was considered the confidence level of $95 \%$, a sampling error of $5 \%$ and minimum percentage of $88.0 \%$, considering the prevalence of parafunctional habits observed in a national study with similar methodology. According to the software (http://www.publicacoesdeturismo.com.br/ calculoamostral/), the minimum n proposed for this study was 163 teenagers. The minimum n stipulated was 171 participants considering a $5 \%$ absenteeism.

All adolescents and their responsible who accepted to participate in the study received clear oral and written instructions about the methodology and objectives of the study and signed the Free and Informed Consent Form (FICT) and the FIAF.

The adolescents with the following conditions were not included in the sample: changes in cognitive functions and impairment of communication skills; the presence of large cavities or lesions in oral mucosa, able to mimic the TMD pain; history of recent trauma on the face; absence of parental consent and/or its own acknowledgement.

The following protocol was used:

Tracking the presence of daytime parafunctional habits, daytime clenching, and sleep bruxism

It was conducted using a self-reporting questionnaire (yes/not) about the habits of nail biting, chewing gums with frequency, biting objects, biting lips/cheeks, support the chin with the hand (adapted from the protocol proposed in the Bonafé ${ }^{16}$ study). To identify the awake teeth clenching and sleep teeth grinding parafunctions, we selected questions $15 \mathrm{c}$ and $15 \mathrm{~d}$ (respectively, "Have you noticed or did someone tell you that you grind or clench your teeth when sleeping?" and "During the day, do you grind or clench your teeth"?, from the Research Diagnostic Criteria for Temporomandibular Disorders (RDC/ TMD $)^{17}$, in its Portuguese version ${ }^{18}$ ). In addition to these reports, the number of extra facial pain complaints were also studied, asking about the presence of pain in the last 3 months in the following areas: neck/shoulders, arms/legs, back, chest/ abdomen. For this study, the answer alternatives were: "yes, always" (2), "yes, sometimes" (1) "no, never" (0). The answers "yes, always" or "yes, sometimes" were considered positive reports. A sum of positive self-reports was obtained. Separately, were also evaluated the reports of sleep bruxism and daytime clenching, dichotomously grouping the answers in yes ("yes, always" or "yes, sometimes") or not.

\section{Questionnaire to identify the practice of physical activity}

The information on the practice of physical activity was gathered in accordance with the tool proposed in the National Research on Students' Health (PeNSE - 2012) ${ }^{19}$. From this questionnaire, we obtained the absolute sum and the results, grouped according to the variables: days of exercise, hours of exercise and hours of reported sedentary activities. The days of exercise were grouped in less than 2 days/week, 2 to 4 days/ week and 5 or more days/week. The hours of exercise were grouped into inactive (less than $300 \mathrm{~h} /$ week) and active (more than $300 \mathrm{~h} /$ week). The hours of sedentary activities were grouped in less than $2 \mathrm{~h} /$ day, $3-5 \mathrm{~h} /$ day and 6 or more hours per day. For data tabulation, the number of days of exercise practiced by the adolescent was multiplied by the time spent for its execution.

This study was approved by the Committee of Ethics of the Institution (CAAE 45104615.1.0000.5383).

\section{Statistical analysis}

The data were computed by the software SPSS para Windows, version 21 , in a spreadsheet especially developed for this purpose. The descriptive statistics were performed, and for the interest associations, we used the Qui-square test adopting a level of significance of $5 \%(\mathrm{p}<0.05)$. For the quantitative variables, the statistical tests were defined in accordance with the distribution patterns (normal and not normal). 


\section{RESULTS}

In the sample, we evaluated 76 adolescent boys (38\%) and 124 girls $(62 \%)$, with an average age of $14.07 \pm 2.789$ years, girls 14.31 years and boys 13.66 years. Most of the adolescents were Caucasian $(\mathrm{n}=117,58.5 \%)$, followed by brown $(\mathrm{n}=54,27 \%)$, black $(\mathrm{n}=27,13.5 \%)$ and yellow $(\mathrm{n}=2,1 \%)$. There was no difference between boys and girls as for the race (Qui-square, $\mathrm{p}=0.300$ ), and age (Mann-Whitney, $\mathrm{p}=0.093$ ). Also, there was no statistically significant difference between genders for the following variables: number of parafunctional habits (Mann-Whitney: $\mathrm{p}=0.5$ ), extra facial points of pain $(\mathrm{p}=0.094)$, sleep bruxism $(\mathrm{p}=0.124))$ e daytime clenching $(\mathrm{p}=0.128)$, and for this reason, tables 4 to 8 were worked with the total sample, without grouping by gender.

The statistical analyses demonstrated that there was a statistically significant difference between genders in terms of days (Table 1), hours of exercise (Table 2) and hours of sedentary activity (Table 3 ). There were no statistically significant differences between the number of points of extra facial pain nor the number of reported parafunctional habits in the categories of days of exercise (Table 4 ), hours of exercise (Table 5) and hours of sedentary activities (Table 6).

Table 1. Days of exercise according to gender

\begin{tabular}{lcccc}
\hline Gender & \multicolumn{2}{c}{ Total } \\
& Less than 2 weeks & 2 to 4 weeks & 5 or more weeks & \\
\hline Male & $10(13.1)$ & $25(32.8)$ & $41(53.9)$ & $76(100)$ \\
Female & $38(30.6)$ & $42(33.8)$ & $44(35.4)$ & $124(100)$ \\
Total & $48(24)$ & $67(33.5)$ & $85(42.5)$ & $200(100)$ \\
\hline
\end{tabular}

$\mathrm{p}=0.007$, significance by the Chi-square test.

Table 2. Hours of exercise according to gender

\begin{tabular}{lccc}
\hline Gender & Minutes of exercises/weeks $\mathrm{n}(\%)$ & Total \\
& Less than $300 \mathrm{~min} /$ week & More than $300 \mathrm{~min} /$ week & $76(100)$ \\
Male & $54(71.1)$ & $22(28.9)$ & $124(100)$ \\
Female & $107(86.2)$ & $17(13.7)$ & $200(100)$ \\
Total & $161(80.5)$ & $39(19.5)$ & 200 \\
\hline
\end{tabular}

$\mathrm{p}=0.008$, significance by the Chi-square test.

Table 3. Hours of inactivity according to gender

\begin{tabular}{lcccc}
\hline Gender & & Hours of inactivity/day $n(\%)$ & & Total \\
& Less than 2 days & $3-5$ days & 6 or more days & $76(100)$ \\
Male & $27(35.5)$ & $22(28.9)$ & $27(35.5)$ & $124(100)$ \\
Female & $33(26.6)$ & $38(30.6)$ & $53(42.7)$ & $200(100)$ \\
\hline
\end{tabular}

$\mathrm{p}=0.008$, significance by the Chi-square test.

Table 4. Descriptive values and statistical difference of the variables studied regarding the categories of days of exercise

\begin{tabular}{lcc}
\hline Days of exercise/week & $\begin{array}{c}\text { Points of extra facial pain } \\
\text { Average } \pm \text { SD }\end{array}$ & $\begin{array}{c}\text { Number of parafunctional habits } \\
\text { Average } \pm \text { SD }\end{array}$ \\
\hline Less than 2 days/week & $1.35(1.08)$ & $3.38(1.39)$ \\
2 -4 days/week & $1.16(0.96)$ & $3.55(1.19)$ \\
5 or more days/week & $1.11(1.11)$ & $3.36(1.39)$ \\
p value & 0,98 & 0,61 \\
Total & $1.19(1.05)$ & $3.43(1.32)$ \\
\hline
\end{tabular}

$\mathrm{p}=$ significance by the Kruskal-Wallis test.

Table 5. Descriptive values and statistical difference of the variables studied regarding the categories of minutes of exercise

\begin{tabular}{lcc}
\hline Minutes of exercises/week & $\begin{array}{c}\text { Points of extra facial pain } \\
\text { Average } \pm \text { SD }\end{array}$ & $\begin{array}{c}\text { Number of parafunctional habits } \\
\text { Average } \pm S D\end{array}$ \\
\hline Less 300min/week & $1.22(1.03)$ & $3.48(1.33)$ \\
More than 300min/week & $1.05(1.14)$ & $3.21(1.30)$ \\
p value & 0,25 & 0,13 \\
Total & $1.19(1.05)$ & $3.43(1.32)$ \\
\hline
\end{tabular}

$\mathrm{p}=$ significance by the Mann-Whitney test. 
Table 6. Descriptive values and statistical difference of the variables studied regarding hours of inactivity

\begin{tabular}{lcc}
\hline Hours of inactivity/day & $\begin{array}{c}\text { Points of extra facial pain } \\
\text { Average } \pm \text { SD }\end{array}$ & $\begin{array}{c}\text { Number of parafunctional habits } \\
\text { Average } \pm \text { SD }\end{array}$ \\
\hline Less than 2 h/day & $1.22(1.12)$ & $3.12(1.23)$ \\
3-5h/day & $1.03(0.97)$ & $3.53(1.33)$ \\
6 or more h/day & $1.28(1.06)$ & $3.59(1.36)$ \\
p value & 0,42 & 0,08 \\
Total & $1.19(1.05)$ & $3.43(1.32)$ \\
\hline
\end{tabular}

$\mathrm{p}=$ significance by the Kruskal-Wallis test.

Table 7. Descriptive values and difference of the variables studied regarding sleep bruxism

\begin{tabular}{lccc}
\hline Sleep bruxism & $\begin{array}{c}\text { Days of physical activity/week } \\
\text { Average } \pm \text { SD }\end{array}$ & $\begin{array}{c}\text { Minutes of physical activity/week } \\
\text { Average } \pm \text { SD }\end{array}$ & $\begin{array}{c}\text { Hours of inactivity/day } \\
\text { Average } \pm \text { SD }\end{array}$ \\
\hline No & $3.76(2.42)$ & $214.10(225.74)$ & $267.20(143.39)$ \\
Yes & $3.72(2.67)$ & $196.08(213.03)$ & $283,08(129.82)$ \\
p value & 0,82 & 0,350 & 0,493 \\
Total & $3.75(2.46)$ & $210.59(222.91)$ & $270.30(140.68)$ \\
\hline
\end{tabular}

$\mathrm{p}=$ significance by the Mann-Whitney test.

Table 8. Descriptive values and difference of the variables studied regarding daytime clenching

\begin{tabular}{lccc}
\hline Daytime clenching & $\begin{array}{c}\text { Days of physical activity/week } \\
\text { Average } \pm \text { SD }\end{array}$ & $\begin{array}{c}\text { Minutes of physical activity/week } \\
\text { Average } \pm \text { SD }\end{array}$ & $\begin{array}{c}\text { Hours of inactivity/day } \\
\text { Average } \pm S D\end{array}$ \\
\hline No & $3.79(2.50)$ & $220.52(237.18)$ & $267.47(144.51)$ \\
Yes & $3.56(2.33)$ & $162.06(124.23)$ & $284.12(121.18)$ \\
p value & 0,62 & 0,10 & 0,47 \\
Total & $3.75(2.46)$ & $210.59(222.91)$ & $270.30(140.68)$ \\
\hline
\end{tabular}

$\mathrm{p}=$ significance by the Mann-Whitney test.

There was no statistically significant difference among the averages of the values of the sum of the days of physical activity, the minutes of physical activity and the hours of inactivity in terms of specific reports of sleep bruxism (Table 7) and daytime clenching (Table 8).

\section{DISCUSSION}

In general, studies using questionnaires to classify the level of habitual physical activity of the population have some operational advantages, such as reaching large groups, be precise, easy to apply and low cost. However, such tools usually do not have good sensitivity to all the components of the physical activity. There is a need for more information regarding the use of questionnaires with Brazilian adolescents. However, we can cite PeNSE, IPAQ, and PAQ-C as methods used in previous studies ${ }^{16,19-25}$. In the present study, we preferred to use the PeNSE since it is a National Research on Students' Health developed by the Department of Health, with nationwide coverage.

Although both genders showed a low level of physical activity, the boys were more active than the girls since they devoted more hours of physical activity, during more days of the week, and this difference is statistically significant. The high level of physical inactivity found in the present study, mainly in females, corroborates the literature data ${ }^{21,23,25}$ and seems to be a trend in the young generation.
Since physical activity reduces the stress that aggravates psychophysical problems ${ }^{4}$, our hypothesis was that physically less active adolescents could present more parafunctions and extra facial pain. However, in this study, the presence and the time of physical activity practiced by adolescents had no significant association with the parafunctional habits, sleep bruxism, daytime clenching, and points of extra facial pain. It was not found in the literature studies confronting the same variables analyzed in the present study correlating to the practice of physical activities. However, in a slightly broader context, authors as Tavares et al..$^{26}$ and Bonafé ${ }^{16}$, studied the practice of physical activity and the presence of TMD, not observing any significant association between both, in line with, even distantly, with our findings. Moreover, although the physical activity in adolescence brings innumerable health benefits, preventing diseases, obesity, insomnia, and stress ${ }^{13,20,25}$ it seems to have little influence on extra facial pain and the presence of parafunctional habits.

Since bruxism/clenching have a multifactorial origin $^{27-31}$, they must be analyzed with caution because many factors can trigger the onset and not only the absence of physical activity. It is worth mentioning that bruxism, as well as parafunctions, generate peripheral sensitization and can lead to local acute pain resulting from the release of inflammatory substances in the muscle and joint tissue. The peripheral sensitization can become a continuous source of pain in the tissue, thus leading to central sensitization ${ }^{4,8-12}$. 
In the adolescence, there is an important increase in mineralization, bone density, and bone mass, which makes the practice of exercises of paramount importance. With aerobic exercises, the central nervous system is also stimulated, releasing higher amounts of endorphins that when entering the bloodstream act in the musculature causing a relaxation sensation and well-being, that theoretically would act as a protective mechanism against bruxism/clenching ${ }^{13}$.

Even with scientific evidence about the importance of daily physical activity, it is known that in most of the schools, adolescents do not receive enough information about the correlation between fitness and health, which collaborate to increase inactivity in teenagers. Perhaps, one way to prevent inactivity in future adult generations is developing strategies and modifying physical education programs in schools, making them more attractive and flexible to meet the desire of the adolescents. According to the American College of Sports Medicine, a good approach to overcome the lack of time is to encourage adolescents to try to accumulate during the day, short periods of exercises with moderate intensity. In relation to the type of activity, it is recommended any activity that uses major muscle groups in a continued, rhythmic and aerobic way (for example, walking, jogging, cycling). Another strategy to increase adolescent's compliance is to facilitate the access to places and facilities to practice physical activities ${ }^{13}$.

Although it was not found an association between the practice of physical activity, parafunctional habits, and extra facial pain, the small number of scientific articles addressing this subject point to the need for future longitudinal studies to better examine the etiologies and mechanisms related to parafunctional habits/ bruxism and to investigate other clinical and psychological variables. This can define a more specific profile of adolescents and provide definitions of vulnerable groups in young populations. Some limitations of this review. We used self-reporting questionnaires not referred in the international literature, although recent publications have used a similar methodology to investigate parafunctional habits in adolescents ${ }^{32,33}$. The sample was not representative of the population which prevents from generalizing the results. In addition, its reduced size limits the use of logistic regression models and more complex statistical analysis.

\section{CONCLUSION}

Boys practiced more physical activities and for longer periods when compared with the girls. However, the practice of physical exercises did not show a significant association with the presence, amount or type of parafunctional habit, nor with the presence of extra facial pain.

\section{REFERENCES}

1. Word Health Organization. Young people's health: a challenge for society. World Health Organization Technical Report Series 731. Geneva: WHO; 1986.

2. Shimshak DG, Kent RL, DeFuria M. Medical claims profiles of subjects with temporomandibular joint disorders. Cranio. 1997;15(2):150-8.

3. Alfaya TA, Zukowska HR, Uemoto L, Oliveira SS, Martinez OE, Garcia MA, et al. Alteraçôes psicossomáticas e hábitos parafuncionais em indivíduos com disfunção temporoman- dibular. Rev Saúde e Pesquisa. 2013;6(2):185-9.

4. Okeson JP. Tratamento das desordens temporomandibulares e oclusão. $7^{\mathrm{a}} \mathrm{ed}$. Rio de Janeiro: Elsevier; 2013. 512p.

5. Alves-Rezende MC, Soares BM, Silva JS, Goiato MC, Turcio KH, Zuim PR, et al. Frequência de hábitos parafuncionais. Estudo transversal em acadêmicos de Odontologia. Rev Odontol Araçatuba. 2009;30(1):59-62.

6. American Academy of Orofacial Pain. Orofacial pain: guildelines for assessment, diagnosis and management. $5^{\text {th }}$ ed. De Leew R, Klasser GD, editors. Chicago: Quintessence; 2013. 301p.

7. Lobbezoo F, Ahlberg J, Glaros AG, Kato T, Koyano K, Lavigne GJ, et al. Bruxism defined and graded: an international consensus. J Oral Rehabil. 2013;40(1):2-4.

8. Gear RW. Neural control of oral behavior and its impact on occlusion. In: McNeill C, editor. Science and practice of occlusion. Chicago: Quintessence; 1997. 50-68p.

9. Mense S, Simons DG, Russel IJ. Muscle pain: understanding its nature, diagnosis, and treatment. Philadelphia: Lippincot Williams \& Wilkins; 2001. 385p.

10. Lund JP. Dor e movimento. In: Lund JP, Lavigne GJ, Dubner R, Sessle BJ, editores. Dor orofacial - da ciência básica à conduta clínica. São Paulo: Quintessence; 2002. 151-63p.

11. Ohrbach R, Fillingim RB, Mulkey F, Gonzalez Y, Gordon S, Gremillion H, et al. Clinical findings and pain symptoms as potential risk factors for chronic TMD: descriptive data and empirically identified domains from the OPPERA case-control study. J Pain. 2011;12(11 Suppl):T27-45.

12. Fernandes G, Franco AL, Siqueira JT, Gonçalves DA, Camparis CM. Sleep bruxism increases the risk for painful temporomandibular disorder, depression and non-specific physical symptoms. J Oral Rehabil. 2012;39(7):538-44.

13. Biazussi R. Os benefícios da atividade física aos adolescentes. [Acesso em 2015 Mai 08] Disponível em: http://pt.scribd.com/doc/39766098/artigo-cientifico-pro-trabalho-de-ed-fisica-1\#scribd.

14. Pires EA, Duarte MF, Pires MC, Souza GS. Hábitos de atividade física e o estresse em adolescentes de Florianópolis. Rev Bras Ci Mov. 2004;12(1):51-6.

15. Merighi LB, Silva MM, Ferreira AT, Genaro KF, Berretin-Felix G. Ocorrência de disfunçấo temporomandibular (DTM) e sua relação com hábitos orais deletérios em crianças do município de Monte Negro - RO. Rev CEFAC. 2007;9(4):497-503.

16. Bonafé FSS. Fatores de risco para a disfunçăo temporomandibular em adolescentes: estudo caso-controle [Dissertaçấo de Mestrado]. Araraquara: Faculdade de Odontologia da UNESP; 2014.

17. Dworkin SF, LeResche L. Research diagnostic criteria for temporomandibular disorders: review, criteria, examinations and specifications, critique. J Craniomandib Disord. 1992;6(4):301-55.

18. Pereira-Júnior FJ, Favilla EE, Dworkin SF. Critérios de diagnóstico para pesquisa das disfunçôes temporomandibulares (RDC/TMD). Tradução oficial para a língua portuguesa. Bras Clin Odontol Integr. 2004;8(47):384-95.

19. Ministério da Saúde (Brasil), Instituto Brasileiro de Geografia e Estatística. Pesquisa Nacional da Saúde do Escolar 2012. RJ: Ministério Saúde; 2013 [Acesso em 2015 Mai 08]; Disponível em: http://www.ibge.gov.br/home/estatistica/populacao/pense/2012/pense_2012.pdf.

20. Silva OB. Questionários de Avaliaçấo da Atividade Física e do Sedentarismo em Crianças e Adolescentes. [Acesso em 2015 Mai 08]; Disponível em: http://departamentos.cardiol.br/ sbc-derc/revista/2009/45/pdf/Rev45-p14-p18.pdf.

21. da Silva RC, Malina RM. [Level of physical activity in adolescentes from Niterói, Rio de Janeiro, Brazil]. Cad Saude Publica. 2000;16(4):1091-7. Portuguese.

22. Matsudo S, Araújo T, Matsudo V, Andrade D, Andrade E, Oliveira LC, et al. Questionário internacional de atividade física (IPAQ): estudo de validade e reprodutibilidade no Brasil. Rev Bras Ativ Fís Saúde. 2001;6(2):5-18.

23. Amorin PR, Faria RC, Byrne NM, Hills AP. Análise do questionário internacional de atividade física em adolescentes. Fitness \& Performance J. 2006;5(5):300-5.

24. Janz KF, Lutuchy EM, Wenthe P, Levy SM. Measuring activity in children and adolescentes using self-report: PAQ-C and PAQ-A. Med Sci Sports Exerc. 2008;40(4):767-72.

25. Rivera IR, Silva MA, Silva RD, Oliveira BA, Carvalho AC. Atividade física, horas de assistência à TV e composiçáo corporal em crianças e adolescentes. Arq Bras Cardiol. 2009;95(2):159-65.

26. Tavares MC, Rocha CO, Resende CM, Barbosa GA. Associaçáo entre frequência de exercícios fisicos e níveis de severidade da disfunção temporomandibular. Extensão e Sociedade. 2012;1(4).

27. Drumond CL, Souza DS, Serra-Negra JM, Marques LS, Ramos-Jorge ML, Ramos-Jorge J. Respiratory disorders and the prevalence of sleep bruxism among schoolchildren aged 8 to 11 years. Sleep Breath. 2017;21(1):203-8.

28. Castroflorio T, Bargellini A, Rossini G, Cugliari G, Rainoldi A, Deregibus A. Risk factors related to sleep bruxism in children: a systematic literature review. Arch Oral Biol. 2015;60(11):1618-24.

29. Saulue P, Carra MC, Laluque JF, d'Incau E. Understanding bruxism in children and adolescents. Int Orthod. 2015;13(4):489-506.

30. Carmoin A, Trdieu C, Blanchet I, Orthlieb JD. Le bruxisme Du sommeil chez l'énfant. ARCPED 4446:1-8.

31. Chen LY, Gau SS. Sleep problems and internet addiction among children and adolescents: a longitudinal study. J Sleep Res. 2016;25(4):458-65.

32. Fernandes G, Franco-Micheloni AL, Siqueira JT, Gonçalves DA, Camparis CM. Parafunctional habits are associated cumulatively to painful temporomandibular disorders in adolescents. Braz Oral Res. 2016;30:e15.

33. Franco-Micheloni AL, Fernandes G, de Godoi Gonçalves DA, Camparis CM. Temporomandibular disorders in a young adolescent Brazilian population: epidemiologic characterization and associated factors. J Oral Facial Pain Headache. 2015;29(3):242-9. 